\title{
Democracy versus Security as Standards of Political Legitimacy: The Case of National Policy on Irregular Migrant Arrivals
}

\author{
Patti Tamara Lenard and Terry Macdonald
}

\begin{abstract}
Democratic citizens confront a range of problems framed as "security" issues, in policy areas such as counterterrorism and migration control, which place substantial political pressure on democratic norms. We develop a normative theoretical framework for assessing whether and how policies that curtail democratic governance standards in the name of security can be justified as politically legitimate. To do so, we articulate a novel normative account of legitimacy, which integrates insights from both democratic and realist traditions of thought to illuminate the complementary contributions of democratic and security standards to political legitimacy. We further elaborate a framework for applying this theoretical account to political practice in the form of a policy-focused "security test" for legitimacy in democratic states. Finally, we explore how this test may be deployed to help resolve policy dilemmas in democratic practice, by examining its application to a case study of national policy on irregular boat arrivals in Australia and Canada. Through this analysis, we contribute to the development of both richer theoretical understandings of the complex modern value of political legitimacy, and clearer action-guiding principles for balancing competing demands of legitimacy within securitized democratic policy regimes.
\end{abstract}

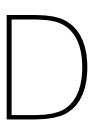

emocratic citizens confront a range of problems framed as "security" issues in policy areas such as counter terrorism and migration control, that place substantial political pressure on democratic norms. Operational demands of security in these domains are commonly invoked as grounds not only for curtailing individually held liberal rights to liberty, privacy, and legal due process, but also for curtailing many collectively held democratic rights to transparency, accountability, and robust public oversight in policy making and implementation (Newey 2012; Zedner 2005; Givens, Freeman, and Leal 2008; Rudolph 2006). While restrictions on individuals' liberal rights have generated longstanding controversies around counterterrorism and associated law-enforcement

Patti Tamara Lenard (D) is Associate Professor of Ethics in the Graduate School of Public and International Affairs, University of Ottawa (patti.lenard@uottawa.ca). She is the author of Trust, Democracy and Multicultural Challenges (Penn State, 2012). Her work has been published in many journals, including American Political Science Review, Political Studies, and Ethics and International Affairs. Her research focuses on the moral questions raised by migration across borders in an era of terrorism, especially as it pertains to refugees and irregular migrants. She is presently writing a monograph about the ways that democratic states should fight the threat posed by global terrorism.

Terry Macdonald is a Senior Lecturer in International Relations at the University of Melbourne, having previously held positions at Merton College, Oxford University, the Centre for Applied Philosophy and Public Ethics at the ANU, and Monash University (terry.macdonald@unimelb.edu.au). She is the author of Global Stakeholder Democracy: Power and Representation Beyond Liberal States (Oxford University Press, 2008) and co-editor of Global Political Justice (Routledge, 2013). She has published widely on topics of democracy, legitimacy, and political justice, and is currently completing a new monograph on global political legitimacy.

They thank the following research assistants for their work on this article: Ikram Handulle, Joshua Knoop, and Emily Look. They also thank the incredibly generous and thoughtful reviewers, who engaged in the best possible way with the arguments they have offered here. The article is much stronger for their work. 
policies, restrictions on collective democratic rights provoke parallel controversies around so-called "border security" policies concerned with deterring, intercepting, or detaining irregular migrant arrivals. Many democratic governments invoke perceived threats to national border security from irregular migrants as legitimate grounds for pursuing bordercontrol policies outside the constraints of normal democratic standards, while opposition groups decry these political moves as illegitimate restrictions on democratic rule.

Here, we develop a normative theoretical framework for assessing whether and how policies that curtail democratic governance standards in the name of security can be justified as politically legitimate. ${ }^{1}$ We treat a legitimate policy as one that is worthy of political support (Buchanan 2013; Macdonald 2016); any legitimacy assessment must therefore begin by identifying the normative standards against which support-worthiness should be judged. The main challenge is the lack of established scholarly consensus on normative standards of legitimacy that are independent from the values of democracy and security themselves; while democratic theories link legitimacy directly to democratic standards (Knight and Johnson 1994; Macdonald 2016), and realist theories link legitimacy closely to security standards through an emphasis on the value of Hobbesian order (Williams 2005), it remains unclear what overarching normative commitments can be invoked to integrate or weigh these competing values. Following from this recognition, we articulate an account of the normative grounds of legitimacy assessments, in terms of which we can justify some role for both security and democratic standards and can guide policy-makers in navigating tensions between them. We thereby contribute to the development of richer theoretical understandings of the complex modern value of legitimacy, and clearer principles for balancing competing demands of legitimacy within security-related policy regimes.

We develop this analysis in three steps. First, we highlight the limitations of established democratic accounts of legitimacy for understanding the normative grounds on which democratic standards could legitimately be curtailed in pursuit of security. This can be better understood, we argue, by invoking a collective agency account of the normative grounds of legitimacy standards. Our proposed account integrates methodological insights from (and beyond) realist theories, which link legitimacy's normative grounds to real-world political problem-solving, with substantive insights from democratic theories, which link them to the value of empowering intelligent collective agency. Drawing these insights together, we claim that institutions or policies are legitimate within some constituency insofar as they empower the exercise of real political forms of intelligent collective agency among its members. We take these to incorporate not only the rationally intelligent collective agency empowered through formal and egalitarian democratic social choice procedures, but also the intelligent practical "know-how" and creativity empowered through more diffusely institutionalized collaborative practices, which constitute the background institutional framework for democratic politics. These include some collaborative practices within social, economic, and cultural spheres, as well as those constitutive of sovereign statehood. By explaining how normative legitimacy can be grounded in the operation of institutionalized practices beyond democratic procedures, this account creates room for the possibility that upholding exogenous values (such as security) can contribute to legitimacy within democracies.

We next consider the more specific normative grounds on which security may serve as a standard of legitimacy, and the conditions under which its protection may override certain democratic standards. We sketch a normative account of what security is, and explain how its protection can strengthen legitimacy by satisfying institutional preconditions for empowering intelligent collective agency, as exercised through and beyond democratic decisionmaking procedures. We translate these theoretical arguments into action-guiding principles for application to policy practice in the form of a prescriptive security test for democratic processes. This identifies three conditions under which it may be legitimate for a government to restrict some democratic standards in the name of security: that the security threat is basic (Shue 1996), in the sense of being a precondition for the institutional capacity of political communities to pursue other kinds of collective interests; that the constraints imposed on democratic standards are proportionate to this threat; and that their justification is public.

We then explore how this test may help resolve policy dilemmas in democratic practice, by examining its application to a case study of policy responses to irregular migrant arrivals by boat in Australia and Canada-two strong democracies whose histories of political debate on the security/democracy nexus in this policy area have served as precursors for some current border-security controversies under the Trump administration in the United States. The application of our theoretical arguments to the case of irregular migration policy serves two analytical purposes. First, it illuminates some important political problems and trade-offs at stake in theoretical arguments about relationships among democracy, legitimacy, and security. Second, it illustrates how our normative arguments can help prescribe legitimate policy frameworks for democratic societies, when tensions arise in political practice between these fundamental values.

\section{Political Legitimacy beyond Democratic Standards: The Institutional Preconditions for Empowered Collective Agency}

Political legitimacy is a fundamental value within many modern societies, though it is also a complex value that 
eludes simple theoretical characterization (Macdonald 2016). We are concerned here with normative legitimacy, understood as the quality possessed by institutions or policies that warrant political support. The conceptualization of legitimacy as support-worthiness is shorthand for a more complex conceptual structure, tracking quadratic relationships among some set of agents, and their reasons, behaviours, and institutions (or institutionalized policies); when we speak of normative political legitimacy, we are making claims about the normative reasons that some political agents have to support their governing institutions or policies. ${ }^{2}$ The concept thus understood can subsume a range of conceptions ${ }^{3}$ - differing in specifications of the sets of agents ("constituencies"), types of reasons ("sources of normativity"), forms of supportive behaviour (obedience, non-interference, resource provision, etc.), and character of governing institutions and policies (state or non-state, legal or non-legal, etc.) under examination. While legitimacy claims can thus be made about international and non-state institutions, most democratic theory and practice historically has been concerned with state-based legitimacy-focused on citizens' normative reasons for supporting states via obedience to the law and participation in the wider range of civic activities associated with citizenship.

Normative theories of legitimacy attempt to characterize the conditions under which such political support is warranted on two levels. First, they prescribe standards typically formulated as required procedural inputs or substantive outputs-that policies or institutions must meet in order to qualify as legitimate. Second, they articulate the underlying normative grounds for these standards - that is, the reasons that count in favour of adopting these standards as criteria of political supportworthiness. Standards of legitimacy-such as those requiring democratic procedures or security outcomes-are the focus of most controversies in policy practice. But since the grounds for resolving such controversies lie in their underlying normative justifications, it is at this justificatory level of analysis that we must begin.

\section{The Normative Grounds and Limits of Democratic Legitimacy Standards}

The twentieth-century ascendency of democracy, as a predominant institutional model for legitimizing power, has reinforced a tight theoretical association between democratic standards and political legitimacy. The question of what counts as a "democratic" standard is a contested matter, with a range of standards defended by theorists as institutional vehicles for democracy. Democratic standards are typically designed to support the operation of formal and egalitarian social choice procedures for political decision-making - though these range across a variety of representative, aggregative, and deliberative models (Held 2006). Competing models of social choice share a commitment to the core democratic values of equality and rationality in political decision-making, but differ in their more fine-grained interpretations of the content and priority of these values. For now, we bracket these controversies by invoking an ecumenical view of democracy, according to which multiple varieties of social choice institution can contribute to the overall democratic character of institutions.

In our case study analysis that follows, we focus accordingly on three minimal democratic standards that serve as common elements across diverse institutional models of democratic social choice. The first is transparency, which demands public availability of information about activities and decisions of public policy makers. The second is accountability, which demands predictable and effective institutional means for sanctioning public policy makers judged by the democratic public or its representatives to have acted beyond their authority or against the public interest. The third is public scrutiny, which demands opportunities for active public participation in critically scrutinizing policy practices, through ongoing access to critical engagement with public institutions and policy-makers by journalists, civil society organizations, and citizens.

These standards are not sufficient to make policy processes democratic; rather, they operate in conjunction with electoral, deliberative, or broader representative procedures for social choice. Nonetheless, they are fundamental to most democratic institutional models because of the important role that they play in facilitating social choice procedures, of whatever variety is adopted. Transparency helps ensure that all relevant information is available to citizens in policy deliberations and decisionmaking processes (Fung 2013). Accountability helps ensure that policies are formulated and implemented in accordance with the democratic mandates defined through social choice procedures (Przeworski and Stokes 1999). Active public scrutiny helps sustain a dialogue between citizens and policy-making authorities that can support more democratically responsive policy than would be achievable through periodic elections alone (Bohman 2000).

Democratic theorists have advanced two main lines of argument about why such democratic standards are important criteria for legitimacy. The first begins with the premise that legitimacy derives from compliance with some moral principles that are more fundamental than the value of democracy itself (Erman 2016). It then claims that democratic standards generate legitimacy insofar as they help satisfy morally obligatory demands for political equality among individuals (Saward 1998; Christiano 2008; Beitz 1989). The second line of argument begins with the different premise that legitimacy derives from some freestanding political value of empowering intelligent collective political agency, understood as a quality of the political processes through which collectives develop and exercise judgment about their governing institutions and 
policies. ${ }^{4}$ This value is often described conceptually in terms of collective "autonomy" or "self-determination" (Miller 1995), and is interpreted by democrats as a system of political decision-making through democratic social choice procedures that embody some kind of "rationality" or "reasonableness" (Landemore 2012), whether institutionalized through "vote" or "voice" in formal aggregative or deliberative procedures (Miller 1992; Dryzek 2001; Knight and Johnson 1994), or through the more informally institutionalized deliberations of a wider democratic "civil society," "public sphere," or "public culture" (Warren 2001; Rawls 2005; Miller 1995). While the rules of democratic social choice procedures still incorporate egalitarian moral principles, this second line of argument is distinctive in according further political value to dimensions of intelligence beyond faculties of moral reasoningsuch as Deweyan "experimental" intelligence (Dewey 1938), and the communicative, practical, and creative faculties exercised in the development and expression of values within public cultures and associations.

While each of these arguments gives a compelling account of how democracy contributes to legitimacy, both present democratic standards as in some way necessary for legitimacy-since the underlying moral obligations or political values that ground legitimacy are interpreted as co-extensive with democracy. As such, neither is able to account for the powerful intuition that standards of democracy and legitimacy may - under some conditions-come apart. This raises a puzzle, since the prospect that democratic standards may legitimately be restricted on security grounds depends on recognizing at least some democratic standards as contingent or partial (rather than necessary or comprehensive) criteria for legitimacy. ${ }^{5}$

The proposition that democracy may sometimes be legitimately curtailed in order to strengthen security presupposes instead, that legitimacy is a substantive political value with some independence from that of democracy, and that the institutional protection of security (alongside democracy) may be one of legitimacy's substantive normative ingredients. To account for this claim and to provide a basis for judgments about when and how democratic institutional standards can be legitimately restricted, we need a broader account of the normative grounds of legitimacy standards, which supplies justifying reasons both for requiring democratic institutional standards under normal circumstances, and for restricting their application under some special conditions. It is to the task of sketching such an account that we turn next.

\section{The Broader Normative Grounds of Legitimacy: Intelligent Collective Agency and Its Institutional Empowerment}

The legitimate relationship between democratic and security standards can be better understood, we propose, by invoking a broader account of the normative grounds of legitimacy that extends beyond the scope of democratic theories. The two predominant democratic accounts of legitimacy, noted earlier, invite extension in different directions. The first invites extension by grounding legitimacy in some broader framework of political morality, such as a theory of justice (Rawls 2005; Valentini 2012), which could in principle designate the protection of security interests as a higher moral priority than democratic egalitarianism, and a potential political trump on democratic standards. An approach of this kind would be theoretically coherent and compelling as a basis for claims about the moral reasons for supporting particular policies. But its adoption would depend on commitment to what Bernard Williams has described as a "moralist" methodological view: that legitimacy standards should be grounded in philosophically derived moral principles, rather than in the "thicker" normative judgments of real political agents (Williams 2005).

Our account of the normative grounds of legitimacy begins instead with commitment to an alternative "political" or "problem-based" methodological view-loosely shared by "realists" such as Williams, as well as others such as some Deweyan pragmatists and liberal contractarians. On this view, the normative considerations that ground standards of legitimacy cannot be wholly reducible to moral principles, insofar as they are intended to function as criteria for real-world political support-worthiness. Standards of legitimacy must be grounded instead in political reasons, which "make sense" to real publics (Williams $2005,11)$, and can motivate collaborative institutional responses to the political problems they jointly experience. $^{6}$ These problems can be defined in very different ways, and institutional or policy responses are correspondingly motivated by different mixes of self-interest and moral concern: for realists like Williams the grounding problem is that of securing "order" (Williams 2005); for liberals like Robert Keohane and Allen Buchanan it is a rationalist "metacoordination" problem (Buchanan 2013; Buchanan and Keohane 2006); while for pragmatists like John Dewey grounding problems are as contextually variable and fluid as the "publics" that define them (Dewey 1946). Each of these formulations can accommodate significant responsiveness to moral reasons within framing definitions of grounding problems. But what distinguishes the political methodological approach is commitment to grounding legitimacy standards in agents' motivating understandings of their own political predicaments and normative priorities, rather than any philosophically-stipulated hierarchy of moral and nonmoral reasons.

This latter methodological view provides a basis for developing what we have seen is the second main account of legitimacy's normative grounds adopted among democratic theorists, which associates them with the substantive 
political value of intelligent collective agency. The concept of intelligence here denotes practical virtues of judgmentthat is, faculties of judgment that are useful to agents in understanding and remedying their experienced problems. ${ }^{7}$ The empowerment of intelligent collective agency can thus generate legitimacy insofar as it institutionally harnesses the faculties of judgment best equipped to remedy the collective political problems to which institutions and policies respond, on terms that reflect agents' own understandings of these problems. Another way of putting this is that the normativity of legitimacy standards derives from the political value of the collective selfdetermination that legitimate institutions can help to empower. As such, an institution or policy is legitimate to the extent that it is able to function as a vehicle for empowering members of some corresponding collective to express and advance their "common interests" in response to shared problems-by coordinating their collective decision-making, executing their collective decisions, and providing safeguards against the abuse of the special institutional powers established for these purposes (Cohen 1997; Benhabib 1994; Macdonald and Macdonald 2017).

This general account of the normative grounds of legitimacy standards allows for significant pluralism in the standards of legitimacy justifiable across contexts: differing political problems may call for the empowerment of differing faculties of intelligent judgment, which may in turn warrant differing institutional instruments as legitimacy standards-some more rational and egalitarian (thus democratic) than others. Elsewhere, one of us develops the implications of this account for understanding international institutional legitimacy, where recognition of scope limitations on democratic standards is more prominent due to the relatively weak role played by democratic standards in existing global governance practices (Macdonald 2019; Macdonald and Macdonald forthcoming). But given our narrower focus here on tensions between security and democracy standards arising in democratic states, our key theoretical challenge is articulating an interpretation of the value of intelligent collective agency that can account for the importance of democratic standards without defining it in wholly democratic terms - as conceptually or institutionally constituted by decision-making through aggregative or deliberative democratic social choice procedures.

Here we propose an interpretation of the political value of empowered collective agency that can reconcile a strong democratic commitment with recognition of some normative grounds of legitimacy exogenous to the democratic ideal. Whereas democratic theory typically understands collective self-determination as constituted by the strongly rational and egalitarian forms of collective agency expressed through electoral and deliberative democratic social choice institutions, we contend that legitimacy can further be strengthened through empowering more institutionally-diffused forms of collective agency expressed through background political practices, operating with some independence from democratic choice procedures as means of forming and expressing common interests within groups. These are valid normative grounds of legitimacy insofar as we are willing to accept that not all intelligent judgments made by political agents are articulated formally through electoral vote or deliberative voice, but rather may also be articulated through less rationalised and egalitarian background processes of public dialogue and justification, or expressed behaviourally within other kinds of social practices (Geuss 2009; Philp 2007; Floyd 2016; Dewey 1938). They may be reflected further in individuals' wider patterns of adaptation and resistance to governance institutions, and expressive of participants' creative intelligence and practical know-how, as well as rational faculties of judgment, in response to experienced problems (Macdonald 2019; Macdonald and Macdonald forthcoming).

As noted earlier, some democrats have recognized such contributions made to legitimacy by quite specific types of collective practices - in particular, the public cultures of nations (Miller 1995; Lenard 2012), and the civil society and economic organizations and networks central to associational democratic ideals (Hirst 2013; Warren 2001). Our account dovetails with these nationalist and associational democratic conceptions of collective selfdetermination, but extends them by emphasizing that the background political practices contributing to the legitimacy of democratic states may extend beyond national cultures and civil societies to include a wider set of background practices, which may not be so strongly rational or egalitarian in form. In the context of the democratic state, these may include the practices constitutive of sovereign statehood itself, and the substantive common interests expressed through them to which background justifications of state institutions typically appeal. ${ }^{8}$ In other words, the legitimacy of democratic states does not derive exclusively from the participation of citizens in democratic social choice procedures. Rather, it derives in part from the behavioural collaborations among citizens required to sustain the substantive functional capabilities that provide the background institutional framework for democratic social choice-including the functions of sovereign state governance, and arguably also some wider capabilities for social, economic, and cultural production.

This broader conception of intelligent collective agency, as the political value that grounds legitimacy standards, accounts for the central role of democratic institutions in articulating and advancing the common interests of collectives-insofar as democratic standards are designed to harness the rational intelligence of all citizens on equal terms, through both formal social choice and wider public oversight. It also leaves space for 
recognition that some subset of collectives' common interests may be defined and advanced outside of democratic procedures-through institutional empowerment within background practices of more diverse dimensions of collective intelligence, including collaborative forms of creativity and practical know-how, as well as individual and collective rationality. ${ }^{9}$ Crucially, this helps us see how a substantive common interest in security-such as that pursued through collaboration in sustaining the wider functional operations of states-could in principle contribute to state legitimacy independently from democratic standards. ${ }^{10}$

\section{Security as a Standard of Political Legitimacy in Democratic States}

To see the implications of this account of legitimacy for the question of whether and when democratic standards may legitimately be restricted on security grounds, more must be said about two matters: first, how should we understand the content of the common interest in security, expressed through practices of state sovereignty within democratic states? And second, how should we understand the relationship of security to democratic standards of legitimacy? We turn to these questions next.

\section{Security as a 'Basic' Institutional Precondition for Empowering Intelligent Collective Agency}

Most extensive debate about the relative normative weight of security concerns has focused, in the post-9/ 11 period, on how security should be balanced against the value of individual liberty (Waldron 2003; Ignatieff 2004; Meisels 2008; Taylor 2018). Many have acknowledged that there are some cases where the protection of security takes sufficient priority that it can justify intrusions on at least some individual liberties (Ignatieff 2004). Others, however, resist the validity of appeals to security as grounds for eroding well-established liberties of (some subsets of) citizens (Williams 2011). These critics challenge not only the substance of some normative arguments for the priority of security over individual liberty, but also the credibility of claims about the "exceptional" status of measures adopted to protect security that restrict individual liberties (Aradau 2004, 393). ${ }^{11}$ Here we are concerned with weighing the importance of protecting democratic norms, rather than civil liberties, in the face of alleged security threats. But there are some important parallels between these topics: both are concerned with defining the conditions under which the common interest in protecting security can legitimately restrict other fundamental political values; and the normative conceptions of security at issue in both cases are the same. As such, we draw on these earlier debates to help formulate the account of security that underpins our analysis.

The type of security with which we are concerned here - a substantive common interest shared by citizens of democratic states, and an ingredient of legitimacyinvolves protection from existential threats of substantive goods defined in four dimensions. First, it involves the physical and material security of individuals, typically associated with military and police protection. This "pure safety" view of security, originating in Thomas Hobbes's account of security offered by the Leviathan, acknowledges that security first and foremost means that one's physical well-being and property are not generally at risk of violence, theft, or other serious crime. ${ }^{12} \mathrm{It}$ is, says Jeremy Waldron, a "radically stripped-down idea" of security (Waldron 2012, 17); but nevertheless any deeper and more substantive conception of security, such as the one that underpins our analysis here, must "remain anchored in the physical safety of men and women" (Waldron 2012, 31; Meisels 2008, 58). The forms of individual safety to be regarded as security protections will vary contextually, and it may sometimes be appropriate to expand them to include wider human security protections, directed against certain social and economic deprivations as well as violence (Goodhart 2005, chap. 7). For our purposes, however, it is adequate to focus on the narrower Hobbesian conceptions of security-since these are the kind invoked in the political arguments we engage with in our case study that follows. ${ }^{13}$

We further understand security to involve a second, future-oriented, dimension-also emphasized by Waldron. To be secure requires not only that one's physical well-being and property are presently protected according to some objective standard, but further that one anticipates this protection continuing into the future (Meisels 2008). To be secure is to believe that we can "make plans and pursue long-term activities to which an advance assurance of safety is integral" (Waldron 2012, 20). This expectational dimension is at least in part subjection, and recognizing this points towards the third distinct feature of our conception of security. Individuals must not only be secure as judged objectively by others, but they must also believe that they are secure: "in an important sense, feeling insecure is to be insecure" (Wolfendale 2017, 240). This feature of security will prove tricky to manage as later sections indicate-for example in cases where security policies aim to assuage citizens' subjective fears instead of targeting their objective security. But here we simply observe that security has this subjective element, and that individuals who are objectively secure, but who do not feel secure, can struggle to make plans for the future effectively. Security is, in part, a "state of mind" (Freedman 1992, 731).

Fourth and finally - and here is where our account of security moves beyond conceptions established in the security versus rights debate-we understand security as in large part a function of relationships among individuals within a society, and as such as a value produced and sustained at a collective level. Many empirical security 
scholars have noted this intersubjective dimension of security-whereby both what we value, and what we believe to constitute threats to our values, are matters of collective experience and discourse (Buzan, Waever, and de Wilde 1998; McDonald 2008). What generates a sense of insecurity in a given society is thereby historically determined - in part by its actual history of security threats, and in part by its collective understanding of what its institutions are meant to protect its citizens from. Where a collective is secure, and believes itself to be secure, individuals can acknowledge their mutual vulnerability and place trust in their co-citizens and institutional values (Loader and Walker 2007; Wolfers 1952; Lenard 2012)). But this way of thinking about security also reveals a possible disjuncture-one that is exploited politically in the case of securitized migration policy as discussed later - between the question of whether a collectivity is secure in the sense of facing objectively credible threats to its collectively-determined values (how likely particular policies are to expose citizens to terrorist acts, for example), and the question of whether its members believe this is the case.

Although public discourse sometimes suggests otherwise, security can never be achieved absolutely (Baldwin 1997, 15); rather, security-subjectively and objectively — can be achieved only in degrees. (Wolfers 1952, 484). Thus, although it may be agreed that matters of national security within democratic states are urgent matters, and that some security threats may warrant special political action, it remains highly controversial which "threats" are of particular concern, and what political responses are warranted. It is in making judgments of this kind that it becomes important to consider how the common interest in security should be weighed against other important political values - and especially, when the nature of "existential threats" to referent goods warrants "endorsement of emergency measures beyond rules that would otherwise bind" political actors (Buzan, Waever, and de Wilde 1998, 5).

To answer this challenge, we treat the primary political value of security as deriving from the fundamental instrumental role it plays in enabling individuals successfully to live their lives and attend to their wider goals and problems, both individually and collectively. This view of security's value can be strengthened by highlighting how it sometimes functions as a basic political interest-i.e., one that is a prerequisite for the capacity to pursue and fulfil other goals. Security has this character insofar as it is true that when individuals are or feel insecure, the pursuit of their wider objectives is more challenging-because insecurity can directly thwart their goals, and divert many energies and resources towards personal protection and away from other activities. This notion of security as a basic common interest of citizens is adapted from Henry Shue's influential idea of "basic rights," whereby rights count as basic "if enjoyment of them is essential to the enjoyment of all other rights ... [such that] when a right is genuinely basic, any attempt to enjoy any other right by sacrificing the basic right would be quite literally selfdefeating" (Shue 1996, 19). ${ }^{14}$ Just as Shue claims that rights are basic when their fulfilment is a pre-requisite for enjoying other rights, so too we propose that security will count as a basic value when achieving it is necessary for sustaining capacities successfully to pursue other individual and collective values. Parallel to Shue's claim that the right to security is among the most basic of individual rights, to be accorded priority in any hierarchy of rights protection, we suggest that security ought to be regarded as a basic common interest of democratic citizens, to be accorded priority in collective public policy-making processes as a key ingredient of their legitimacy.

\section{Weighing Security and Democracy Standards: Towards an Operational Security Test for Legitimate Policy-Making}

Having discussed in turn the normative relationships between democracy and legitimacy and legitimacy and security, our final step is to consider how democratic and security standards should interact within legitimate policymaking processes. The central question here is under what conditions is security at risk such that we should contemplate curtailing some of the democratic standards that are usually regarded as fundamental requirements for legitimacy? Our answer is that democratic standards can be legitimately over-ridden by security concerns only if it can be publicly demonstrated that the specific security issues at stake really qualify as basic in the sense outlined earlier, such that there is an existential threat either to the operation of democratic procedures themselves, or to other important background practices (such as sovereign state governance structures) that operate together with democratic procedures to empower the broader collective agency of democratic societies.

This allows that some democratic standards can be legitimately curtailed on security grounds if doing so will best support the empowerment of collective selfdetermination considered holistically. This follows from our earlier argument that legitimacy does not derive from democracy all the way down, insofar as the basic common interest in security extends to the protection of some background collaborative practices that are not themselves democratic. But it remains consistent with the democratic intuition that no security operation can legitimately bypass all democratic standards; at a minimum, legitimacy requires security operations to satisfy some broad criterion of publicity and public justification-since citizens must ultimately remain empowered to assess for themselves whether the interests at stake in security operations are congruent with their own understandings of their basic common interests. On this basic requirement, there is 
a substantive overlap between the demands of democracy and legitimacy. This need not always involve the strongest forms of democratic control. Security policy need not be pursued through formal democratic decision-making procedures in cases where basic interests are at stake and greater operational intelligence (experience, skill, creativity, and so on) can be harnessed through other state instruments. But no policies can legitimately be severed entirely from the scrutiny of intelligent publics, as a minimum political restraint.

We can extrapolate from these theoretical considerations an operational security test comprised of three evaluative criteria, which can help to structure normative assessments of the legitimacy of policies that restrict democratic standards in the name of security. Whenever a government invokes security concerns to justify a policy that violates democratic institutional standards, we propose, the following criteria must be satisfied for it to be judged legitimate.

First, the security threat must be imminent and pressing-what Rita Floyd has termed an "objective existential threat" (Floyd 2011, 428) —and of a kind reasonably predicted to cause grave harm or impede the ability of the state to advance citizens' interests in the long term. One historical example of such a threat was that posed to the United States by the Cuban Missile Crisis in 1962; had the Soviet missiles been launched, they would have undermined security in the United States to a level where its institutions would have been unable to provide many crucial collective goods. As our earlier analysis indicated, a state's democratic procedures and background practices depend on a basic level of security in order to be effective; protecting them is therefore a necessary condition for the state's ability to pursue citizens' collective interests.

Second, the proposed action must be proportional to the threat faced, as measured by its clear and evident connection to the threat itself (Floyd 2011, 433). In arguing for proportionality, the government must be prepared a) to offer a defense of the proposed policy as the least bad with respect to the violation of democratic standards and b) to acknowledge explicitly that democratic standards are being sacrificed and for how long in order to achieve the security goal. Since only imminent and pressing threats can justify restricting normal democratic standards of legitimacy, the government must be prepared to accept a time limit on a democracy-restricting policyand one that corresponds reasonably with the threat's anticipated duration.

Third, credible evidence for the relevant security threat must be made available for public scrutiny. Here, it may be that in the case of an imminent threat, there is inadequate immediate opportunity for public scrutiny; but government actors must be prepared at least retrospectively to offer evidence publicly in support of the need to sidestep certain democratic standards under those circumstances. This criterion is important to preserve the status of democratic standards as the default or normal standards of legitimacy, by placing the onus on those who seek exceptions to demonstrate that the particular security interests at risk are basic in the requisite sense. Earlier we noted that legitimacy depends on the opportunity for participatory public scrutiny; this condition requires that the evidence that motivates government action be provided to citizens for their independent evaluation. Absent such evidence, citizens will not be able to guard adequately against abuses of state power.

Interpretation and application of these criteria may be complicated by three features of real political debates about security, which reduce their determinacy. First, it is common in political practice for claims of security threats to be formulated in anticipatory terms, and policy responses to be correspondingly justified as pre-emptive measures. It may thereby be unclear what secondary criteria should be used to evaluate security risks of alternative policies, given the inherent uncertainties surrounding future circumstances. Second, democratic publics are often deeply divided in understandings of the content of their common security interests-reflected for instance in controversies about whether threats to ethnocentric national identities posed by irregular migration count as security threats. This wide scope for divergent interpretations of basic security interests and threats, and proportionate responses, points to the need for more extensive normative debate and institutional codification of both the content of common security interests and the (normative and epistemic) criteria for assessing security risks, as part of standard institutional frameworks for ensuring policy legitimacy. Core democratic conceptssuch as "equality" and "rationality"-are similarly open to divergent interpretations; as such, their institutional applications are typically accompanied by rigorous theoretical justifications and explicit institutional codification. To the extent that security claims are invoked as standards of legitimacy that can sometimes override democratic processes, our argument affirms the importance of formulating criteria for the interpretation and application of security standards with a similar degree of precision and publicity.

Third, and perhaps most challenging, many political decisions oriented towards protecting security over the longer term are conducted in secret-arguably necessarily. The purpose of the public scrutiny criterion is to emphasize that democratic citizens are entitled to the information needed to judge their representatives' decisions. With access to this information, citizens ordinarily exercise oversight via the electoral system, public deliberation, and public opinion (Sagar 2013). Yet some decisions aimed at protecting national security do require some secrecy-security agencies cannot reasonably make 
public whom they believe are threats warranting surveillance for example. How should the public scrutiny criterion operate, then, if we take seriously such secrecy requirements?

It is important to recognize that we are not forced to decide here between two polarized alternatives: total absence of oversight for policy choices made in secret (for example in the form of full ministerial discretion on security matters); or guaranteeing full access to information for all citizens at all times. Rather, between these extremes is an extensive range of institutional possibilities, which can empower public representatives to scrutinize security agencies' conduct, including wider authorization of judicial review; establishment of special review tribunals staffed with intelligence experts, or parliamentary/congressional oversight committees; disclosure regulations that determine when secret information will be disclosed; and so on (Sagar 2013, 410). ${ }^{15}$ Such measures are not fully democratic, in the sense that they fall short of what democratic standards normally require. Yet they allow for a kind of public scrutiny that accommodates the need for secrecy on some specific security matters. Where security agencies identify a specific and imminent security threat, retrospective scrutiny is a reasonable expectation. In the face of more diffuse and ongoing threats that predictably warrant ongoing secrecy-such as may be the case with domestic terrorism threats-legitimacy requires creating purpose-built institutions that simultaneously preserve the necessary secrecy and represent citizens' interests in overseeing security operations.

\section{Democracy, Security, and Political Legitimacy in Practice: The Case of Irregular Migration Policy in Australia and Canada}

To illustrate some applications of our theoretical arguments, we turn to a brief case study of national policy responses to irregular migrant arrivals by boat in Canada and Australia. Our objective is to highlight one domain of migration policy that has become securitized in ways that threaten democratic standards. There is nothing new about democratic governments treating particular categories of migrants as threats to security; this way of villainizing migrants has a long history, manifest most recently in worries about would-be migrant terrorists from Middle Eastern countries (Whitaker 1987; Watson 2007; Burke 2008). It bears observing that historical records suggest the fear of migrants is typically unjustified; migrants rarely, if ever, pose security risks of a kind that warrant undermining democratic standards, and we argue here that such restrictions are unwarranted in the case of contemporary irregular migrant arrivals to Australia and Canada. ${ }^{16}$ Nevertheless, this is an instructive case because it is an area in which tensions between democratic and security standards are the focus of major ongoing political controversies across democratic states.
These tensions are particularly sharp in Australia and Canada. While these countries have strong histories of successful migrant integration-in 2015 international migrants comprised $28.2 \%$ of the total population in Australia and $21.8 \%$ in Canada, substantially higher than other democratic "immigrant nations' such as Germany (14.9\%), the United States (14.5\%), or the UK (13.2\%) (UN 2015) - both have been exposed recently to threats of domestic terrorism, linked by some political commentators to open immigration practices. It is illuminating to examine both countries because while Canada has a reputation for welcoming refugees (especially under its current government), compared to Australia's reputation for harsh treatment of asylum seekers (due to its off-shore detention practices and boat turn-back policies), they nevertheless have both securitized irregular migration policies—and invoked this as grounds for eroding democratic standards -on similar terms.

In the following section, we illustrate how the democratic standards outlined earlier have been weakened within policy developments around responses to irregular boat arrivals in Australia and Canada. We examine critically justificatory arguments-articulated in parliamentary debates on migration legislation, and in statements by government and opposition politicians in mainstream media - in support of weakening democratic standards on national security grounds. Finally, we show how our normative security test can serve to structure normative critique of these controversial policies and justifications, and aid the systematic development of more robustly legitimate policy frameworks for responding to irregular migration.

\section{Democracy versus Security in National Policy on Irregular Migrant Arrivals by Boat}

In recent political practice, both Australian and Canadian governments have attempted to justify security-based restrictions on democratic standards in the management of irregular boat arrivals, through appeal to two distinct security threats. First, such arrivals have been presented as threats to national "sovereignty," understood as the political right of territorial control. In Australian parliamentary debate in 2001, for instance, Minister Ruddock emphasized that "the protection of our sovereignty, including Australia's sovereign right to determine who shall enter Australia" is a key political priority (Commonwealth Parliament of Australia, 2001a , 30872), and that "strengthened powers to deal with people who arrive unlawfully" are thereby warranted (Commonwealth Parliament of Australia 2001a, 30871). Similarly, Canadian government representatives have highlighted the dangers posed by irregular boat arrivals to the integrity of Canada's asylum rules, and more broadly the authority of Canadian laws (Liew 2011, 26; Parliament of Canada 2012a). Second, both governments have argued that unauthorized 
boat arrivals threaten national security by fostering criminality (Commonwealth Parliament of Australia 2001a, 30869; Hurst 2015), and elevating the risk of terrorism (Commonwealth Parliament of Australia 2001b, 30954). In defending new legislative provisions focused in part on irregular arrivals to Canada, for instance, Minister Kenney claimed that

the protection of our borders and of Canadians is our highest obligation, and we are making these changes because ... transnational human smuggling ventures are frequently launched from areas of the world where terrorist and criminal organizations are known to be active. (Parliament of Canada 2012a)

He said additionally that "Canadians are worried when they see ... illegal migrants who paid criminal networks to be brought to Canada in an illegal and very dangerous manner" (Parliament of Canada 2012b). Other justifications have appealed to more indirect security threats-in Australia, through instrumental claims that these policies effectively deter unauthorized boat voyages towards Australia (Expert Panel on Asylum Seekers 2012, 12; Phillips 2014); and in Canada, through the use of securitized rhetorical terms such as "bogus," "crackdown," "abuse," "protection," "take advantage," "security of the population" (Parliament of Canada 2012c), and so on, in rationales for these policy changes.

More specifically, in Australia, the management of irregular boat arrivals has been increasingly securitized beginning with the so-called "Tampa Affair" of 2001 (Fox 2010), in which the government denied a Norwegian freighter (the $M V$ Tampa) permission to enter Australian waters. The freighter was carrying several hundred rescued asylum seekers, who ultimately disembarked on the Pacific Island nation of Nauru for detention and processing. This incident spurred legislative and policy developments that reinforced a hardline political stance towards irregular boat arrivals_-including military interceptions and "turnbacks" of unauthorized asylum seeker boats, detention of their passengers, and excision of Australian territories from the Australian migration zone (Commonwealth Parliament of Australia 2001c). Successive Australian governments have further securitized Australia's border control activities - for example, through growing administrative integration of military and bureaucratic arms of migration governance infrastructures (Howard 2003; Department of Defence 2015; Border Department of Immigration Department of Home Affairs 2019).

In Canada, the arrival by boat of unauthorized migrants is less frequent than in Australia; since 1986, only 1,500 individuals have arrived at Canadian shores. Yet the response to these arrivals has nonetheless been increasingly securitized, since at least the mid-1980s (Watson 2007). The most recent boat arrivals-the $M V$ Ocean Lady in October 2009 and the MVSun Sea in 2010, which both docked in British Columbia carrying mostly asylum seekers from Sri Lanka-were simply the latest casualties of an increasingly securitized migration policy environment. By the time these ships arrived, the Immigration Refugee and Immigration Protection Act 2001, and several subsequent amendments to it, had already constructed an infrastructure for treating boat arrivals as security risks. In particular, legislative changes adopted through the 2000s had already sought to portray irregular arrivals as dangerous simply because of their mode of arrival (Silverman 2014). These changes had already made space for the use of discretionary detention of irregularly arriving migrants, by a) designating all adult boat arrivals as irregular and b) identifying all irregular arrivals as automatically detainable (Government of Canada 2012). Citing worries about the dangers these possible terrorists and criminals posed to Canadian national security (perhaps for their possible links to the Tamil Tigers) adult migrants were immediately detained (Youssef 2010). In Stephanie Silverman's words, the arrival of these two ships simply prompted the Canadian government to "formalize its use of mandatory immigration detention" (Silverman 2014, 28). Governments in Australia have similarly responded to irregular arrivals with increased use of mandatory detention. Mandatory detention of noncitizens arriving in Australia without a valid visa, accompanied by special restrictions on judicial review, has been in place in Australia since the Migration Reform Act 1992; and these provisions have been extended in the securitized post-Tampa policy era. Most significant has been the shift of immigration detention for irregular boat arrivals to the third-party states of Nauru and Papua New Guinea (PNG) (Mathew 2002, 664; Phillips 2014; Commonwealth Parliament of Australia 2012a, 2012b).

This sketch gives a simplified picture of the legislative changes adopted in response to irregular arrivals in Canada and Australia. But it is adequate to lay the groundwork for illustrating how this securitized response has incorporated various restrictions on the democratic standards of transparency, accountability, and public scrutiny that are routinely applied within other policy areas. In Australia, transparency has been significantly restricted at both operational and administrative levels. Perhaps most significantly, the administrative reforms initiated through the Australian Border Force Bill 2015 (Commonwealth Parliament of Australia 2015) incorporated new "secrecy and disclosure provisions," establishing that government employees and contractors engaged in border-control related activities_-including many medical and humanitarian workers caring for asylum seekers in offshore Australian detention centers- "must not make or disclose protected information" about governmental operations, subject to a penalty of two years' imprisonment.

Boat interceptions and turn-backs have been subject to additional levels of secrecy within government-to-public communications. This secrecy resulted from an explicit decision by the new Coalition government, after the 
2013 federal election, to reduce public communication on boat turn-back matters to the uniform message: "border Protection Command does not comment on current operational information" (Tranter 2014). Prime Minister Abbott defended this systematic information black-out on the grounds that

there are all sorts of things that our security agencies do that they need to do to protect our country and many of those things just should never be discussed in public. Operational matters, when it comes to national security, are never discussed in public and that's the way it should be. (Hurst 2015)

Moreover, transparency and public scrutiny have been restricted as a function of the jurisdictional divisions and complexities associated with locating and detaining asylum seekers in third party states. For example, Nauru introduced in 2014 an increase in the non-refundable application fees for journalists' visas from $\$ 200$ to $\$ 8,000$ -effectively limiting the media scrutiny of Australian detention facilities (Jabour and Hurst 2014). Furthermore, 2015 changes to Nauru's Criminal Code apply penalties of up to seven years' imprisonment for political speech judged "likely to threaten national defence, public safety, public order, public morality or public health" (Farrell 2015). These changes restricted the rights of Nauru-based asylum seekers or advocates to protest detention conditions, or contribute to Australian public debate. In PNG, serious concerns were raised by the Australian government's attempts to evade public scrutiny for its role in the fatal riots at the Manus Island detention facility in 2014, by attributing responsibility to PNG; as one commentator put it, Australia stood accused of having "outsourced its responsibility for asylum seekers to an unsuitable outpost of one of the least-suitable nations in its region" (Wright 2014).

Paralleling the Australian case, the Canadian policy regime has incorporated significant restrictions on democratic standards. First, accountability has been curtailed in relation to the detention of unauthorized boat arrivals, with expansive ministerial discretion over detention decisions. In particular, Bill-C31 (Protecting Canada's Immigration System Act), which came into force in 2012, permits the Minister of Public Safety to respond to situations where two or more individuals arrive together by officially designated them "irregular arrivals" (no reason-giving required); those so designated face mandatory detention for the period of one year (pending reviews at fourteen days and six months) (Canada 2012). Transparency has also been truncated by these policies, insofar as information about detainees has been publicly withheld on public safety grounds. Of particular concern, the Minister is not required to provide evidence that those detained are dangerous to Canadian national security, and there exist only minimal opportunities for appeals or review (Library of Parliament, Bill C-31, 2012). Absent this information, opportunities for public scrutiny of governmental deci- sions and action — by either refugee advocates and lawyers, or a wider democratic public_-are also minimal.

\section{Assessing the Legitimacy of Securitized Policy on Irregular Boat Arrivals: A Framework for Normative Critique}

Having illustrated how democratic standards have been restricted in the name of security within some important areas of policy practice, we next consider how our theoretical framework can structure normative critique of these practices, and the justificatory arguments advanced for them within political debates. Our security test's three evaluative criteria can help to structure ongoing political critique of securitized policy practice: by articulating principled normative grounds for challenging ad hoc appeals to security as justifications for restricting democratic standards; by identifying policy areas that appear prima facie to be problematic from the perspective of legitimacy, and thereby highlighting key normative questions for citizens and policy practitioners to pursue further through more fine-grained critical analysis.

How can our proposed normative theoretical framework and security test help identify legitimacy challenges posed by these securitized irregular-arrival policy regimes and their justificatory rationales? First, our test directs us to consider whether the security threats to which these policies are responding are sufficiently serious so that basic security interests are at stake? It does seem clear at least that many of the threats identified by these governments within this policy domain qualify as security threats in general terms. Abstract claims about threats to sovereignty are plausible as security claims in principle, though to count as security threats there must be more at risk than the mere idea of sovereignty-such claims must translate into a concrete threat to the operation of some specific sovereign institutions. Concretely, when asylum seekers arrive without having been subjected to the usual scrutiny of the visa application process, or without valid identity documents, there is some risk that individuals may be implicated in terrorist, criminal, or otherwise fraudulent activity. Such risks may warrant some governmental policy response.

However, while the scale and seriousness of the threats posed by criminal or terrorist elements among irregular boat arrivals, or threats of large-scale inundation by boat arrivals, could threaten basic security interests, in neither Canada nor Australia has either government provided evidence that this is in fact the case. Rather, since the numbers of irregular boat arrivals in Australia are small by international standards - and even smaller in Canada - it is difficult to see how the potential threats emanating from these arrivals could be construed as sufficient to undermine the preconditions for routine democratic processes or other background collaborative practices. On this preliminary assessment, the policies we have discussed appear 
be problematic when judged against the first component of our security test. Our framework invalidates appeals to vague and abstract security threats, and demands more nuanced argumentation that appeals to publicly codified —and thus democratically contestable-conceptions of common security interests.

Our security test also directs us to consider whether the scale of the political response to these security threats-in terms of the restrictions on democratic standards-is proportionate to the seriousness of the threat. Notice that the question of proportionality arises only if some plausible prima facie case can be made that restrictions on democratic standards are required to protect basic security interests, yet, as we have argued, it is not clear how such a case can be made in relation to these Australian and Canadian policies. How, though, should these policies be assessed in relation to the proportionality test if it could be demonstrated that some kind of threats to basic security interests were in fact at stake?

While the presence of such security threats may justify certain elements of the new policy regimes-such as initial and brief detention of irregular boat arrivals to establish identity-it is difficult to see how other elements could be judged as proportionate to the threats involved. In particular, restrictions on accountability via restricted opportunities to review asylum and detention decisions, and restrictions on the transparency and public scrutiny of military interception and offshore detention practices, offer little direct protection for any basic security interests. At best, it could be argued that they provide weak indirect protection, by helping to deter future irregular migrant arrivals. But such indirect and weak forms of protection do not satisfy any plausible interpretation of a proportionality demand, given the serious costs incurred to democratic standards of legitimacy in the process. Moreover, insofar as these arguments rest on anticipatory claims about future security threats and pre-emptive claims about proportionate political responses, our framework requires those who seek to restrict democratic standards to publicly codify criteria for assessing security risk —including what kinds of risks it is reasonable for citizens to bear-to demonstrate the proportionality of these restrictions.

Finally, our framework suggests that the onus is on those who want to suspend normal democratic standards to propose and defend such criteria and make a persuasive public case that they have been satisfied. This requirement is incorporated in the third element of our security test, which raises the question, is the political justification for restrictions on democratic standards - in both seriousness and proportionality terms - publicly made within some appropriate timeframe?

Here we found little evidence, in relation to either Australian or Canadian policies, that this public justification requirement has been satisfied within recent practice. In both cases, the substance of public justifica- tions offered for restrictions on democratic standards has been predominantly rhetorical; analysis of the scale and substance of security threats and the proportionality of policy responses has been thin or absent in governmental rationales. Yet even if the need for such secrecy could be vindicated within short operational timeframes, this would not warrant the more enduring and institutionalized forms of governmental secrecy. As such, the application of our security test raises an important normative challenge to status quo practice: it points first to the need for stronger frameworks for public justification of policy regimes on irregular migrant arrivals-incorporating at a minimum reasonable sunset clauses on any restrictions on operational information; more generally, it highlights the need for more extensive critical investigation of how these public justification processes could feasibly be reformed to strengthen overall legitimacy.

A critic might observe that our border security case study does not tell us much about legitimate policy responses to wider and deeper security threats such as those posed by domestic terrorism. We acknowledge this objection. In general terms, our proposed strategy for resolving tensions between security and democracy will in some cases work to strengthen democratic standards, especially where security claims have over-reached in problematic ways, and in others support stronger scope restrictions on democratic standards to ensure adequate security protection. Our illustrative analysis has not been intended to capture the full range of applications of our theoretical framework, but simply to illuminate the dangers of security over-reach in one politically prominent and morally significant policy area within contemporary democratic practice. A wider range of democratic restrictions may well qualify as legitimate in responses to domestic terrorism.

Nonetheless, we want to point briefly to one key detail of our security test that has important implications for cases of more serious security threat. In elaborating our security test, we observed the importance of public justification, but also noted the need for thinking flexibly about how democratic institutions can meet demands for public justification, without compromising the secrecy sometimes needed to protect security. It is reasonable to expect that in cases of more serious and ongoing security threats such as may be posed by terrorism, opportunities for public justification will be more restricted-less inclusive and participatory, and less egalitarian - than in the border security case. Nonetheless, legitimate restrictions on public transparency cannot altogether bypass appeal to the empowered intelligence of democratic publics: no security threat—even one considerably more serious than irregular migration-can support a wholesale and enduring substitution of democratic standards with extensive discretion accorded to a narrow set of individuals operating in secrecy; rather, a commitment must be made 
to more creative institutional development, aimed at ensuring that democratic restrictions themselves remain a matter on which empowered collective intelligence can render political judgment.

\section{Conclusions}

Our goal has been to advance normative debates about how tensions within securitized policy practice between national security objectives on the one hand, and democratic standards of transparency, accountability, and public scrutiny on the other, can be resolved. To this end we have presented: a normative theoretical analysis of the relationships among the political values of democracy, legitimacy and security, on which judgments about these complex political trade-offs must be grounded; based on this normative analysis, a security test for guiding assessment of the legitimacy of policy practices that curtail democratic standards; and an illustration of how this security test can be applied in policy practice, via an application of our normative security test to an empirical case study of policies concerning irregular migrant arrivals in Australia and Canada.

This security test needs more development-including tailoring to specific policy dilemmas within varying national contexts - before it could be used as a prescriptive policy tool. But our examination of its implications for our case study of securitized irregular migrant arrivals in democratic states indicates how this rough set of evaluative criteria can nonetheless help with the more modest task of setting agendas for further empirical inquiry and political critique concerning the legitimacy of securitized policy practice. This mix of empirical and normative theoretical analysis shows that security does not provide an absolute trump on democratic standards of legitimacy within democratic states, but rather a highly conditional and partial one. We have identified key focal points for ongoing critical scrutiny of governments that invoke security rationales to justify policy practices that restrict normal democratic standards of legitimacy.

\section{Notes}

1 We use the term "policy" broadly, to subsume all principled frameworks for guiding political decisionmaking and action, whether formally institutionalized (e.g., in law) or applied on a more discretionary basis (e.g., in guiding operational activities of state agencies). The terms "political legitimacy" and "legitimacy" are used interchangeably.

2 This account of legitimacy is elaborated in Macdonald 2019; Macdonald and Macdonald forthcoming.

3 By "conceptions" we mean fine-grained specifications of broader "concepts."

4 By "political agency" we mean politically consequential activity guided by judgment-based political atti- tudes, or "interests." Political agency is collective when these motivating attitudes are shared among many individuals, constituting common interests. The question of how such a political collective should be bounded raises contentious theoretical issues that we cannot settle here; to simplify our analysis, we bracket this question by focusing on collectives comprised of citizens of democratic states. Agency is "intelligent" if its attitudes are based on judgments that deserve respect for their useful role in defining or advancing interests in response to experienced problems (Dewey 1938).

5 The tension between democratic and security standards points towards a larger puzzle within democratic theory about the legitimate scope limits on democratic standards - that is, the range of policies or institutions to which they apply. Most recent debate about democratic "boundaries" have focused instead on democracy's "domain" - the boundaries of its decision-making community or demos; the "scope" question thus warrants more attention than it has thus far received (Macdonald 2017).

6 The character of this political normativity, and its relationship to moral normativity, raise large methodological controversies that we cannot settle here. For discussion see Rossi and Sleat 2014. One author addresses these methodological issues more fully in Macdonald 2019, in defence of a problem-based situational practice-dependence in the development of the normative theory of legitimacy.

7 While we borrow this general idea of intelligence from Dewey (1938), we are not strictly Deweyan in our interpretation of the range of substantive faculties it may subsume.

8 Beyond background practices of sovereignty, the scope limitations on democratic processes many democrats concede to the operation of global economic and political institutions provide additional - albeit controversial - examples of the wider practices in which legitimacy could arguably be achieved without strong democratic oversight (Macdonald 2018).

9 Intelligent collaboration through background practices may not always satisfy the formal egalitarian standards that in part define democratic processes; but it is precisely in this sense that we are offering an argument for understanding the legitimate scope limits on democracy, rather than a new conception of democratic legitimacy. Specifying what thinner (or at least different) forms of political equality may be required as conditions for the legitimizing functions of (non-democratic) background practices is a larger task than we undertake here, though one of us pursues this elsewhere (Macdonald 2019).

10 While the idea of democracy can incorporate some broader practices within a conception of democratic 
self-determination, empowering other (practical and creative) dimensions of intelligent judgment may require compromising egalitarian and rationalist credentials of judgment-making processes. Rather than trying to incorporate all good (or legitimate) things under the conceptual umbrella of democracy-and thus diluting the egalitarianism and rationalism of the democratic ideal-it is more illuminating to preserve democracy as a distinct conception within a broader concept of legitimacy as empowered collective intelligence.

11 More generally, some related discussions in political theory and securitization studies focus on whether there are "emergencies" that qualify as "states of exception," which justify executive emergency powers. See Agamben 2005; Lazar 2009; Williams 2011 and 2015.

12 For a review of the history of political thought on conceptualizing security, see Lazarus 2015.

13 We acknowledge that definitions of the scope of individual security protections may have implications for how extensively security claims can legitimately curtail democratic standards; settling controversies about this scope is a larger task than we can undertake here.

14 We are not alone in recognizing the importance of Shue's insight in building an account of security. See also Waldron 2003; Meisels 2008.

15 Sagar is skeptical that such oversights can work: instead he defends "leaking" as one key component of transparency mechanisms, for which he needs to argue first that other mechanisms for securing transparency are faulty. We acknowledge that each of these mechanisms brings dangers, but argue that an appropriate institutional setup, required to protect transparency, is morally defensible and practically achievable.

16 There is extensive literature outlining the myriad ways borders have been securitized in the past. See Salter 2008; Zureik and Salter 2005.

\section{References}

Agamben, Giorgio. 2005. State of Exception: Chicago: University of Chicago Press.

Aradau, Claudia. 2004. "Security and the Democratic Scene: Desecuritization and Emancipation" Journal of International Relations and Development 7: 388413.

Baldwin, David A. 1997. "The Concept of Security." Review of International Studies 23: 5-26.

Beitz, Charles R. 1989. Political Equality: An Essay in Democratic Theory. Princeton, NJ: Princeton University Press.

Benhabib, Seyla. 1994. "Deliberative Rationality and Models of Democratic Legitimacy." Constellations 1(1): $26-52$.
Bohman, James. 2000. Public Deliberation: Pluralism, Complexity, and Democracy. Cambridge, MA: MIT Press.

Buchanan, Allen. 2013. The Heart of Human Rights. Oxford: University Press.

Buchanan, Allen and Robert O. Keohane. 2006. "The Legitimacy of Global Governance Institutions. Ethics \& International Affairs 20(4): 405-37.

Burke, Anthony. 2008. Fear of Security: Australia's Invasion Anxiety. Cambridge: Cambridge University Press.

Buzan, Barry, Ole Waever, and Jaap de Wilde. 1998. Security: A New Framework for Analysis. London: Lynne Rienner Publishers.

Canadian Council of Refugees. 2012. "Canada Rolls Back Refugee Protection Bill C-31 Receives Royal Assent." https://ccrweb.ca/en/bulletin/12/06/29.

Christiano, Thomas. 2008. The Constitution of Equality: Democratic Authority and Its Limits. Oxford: Oxford University Press.

Cohen, Joshua. 1997. "Deliberation and Democratic Legitimacy." In Deliberative Democracy: Essays on Reason and Politics, ed. James Bohman, 67-92. Cambridge: MIT Press.

Commonwealth Parliament of Australia. 2001a. "House of Representatives Parliamentary Debates, Official Hansard." 18 September: Columns 30869-30871. . 2001b. "House of Representatives Parliamentary Debates, Official Hansard." 19 September: Column 30954.

- 2001c. Migration Amendment (Excision from Migration Zone) Bill 2001. Retrieved August 3, 2015. http://www.aph.gov.au/Parliamentary_Business/Bills_ Legislation/Bills_Search_Results/Result?bId =r1413 _. 2012a. "Migration Amendment (Unauthorised Maritime Arrivals and Other Measures) Act 2012". Commonwealth, Memorandum: Column 1. Retrieved August 3, 2015 (http://www.aph.gov.au/Parliamentary_ Business/Bills_Legislation/Bills_Search_Results/Result? $\mathrm{bId}=\mathrm{r}$ 4920). . 2012b. "Migration Legislation Amendment (Regional Processing and Other Measures) Bill 2012." Commonwealth. Retrieved August 3, 2015 (http:// www.aph.gov.au/ParliamenD2tary_Business/Bills_ Legislation/Bills_Search_Results/Result?bId=r4683).

_ 2015. "Australian Border Force Bill 2015." Retrieved August 3, 2015 (http://www.aph.gov.au/ Parliamentary_Business/Bills_Legislation/Bills_Search_ Results/Result?bId=r5408).

Department of Defence. 2015. "Border Protection News: Operation Resolute.” Retrieved August 3, 2015 (http:// www.defence.gov.au/operations/borderprotection/).

Department of Home Affairs. 2019. Organisational Chart: Joint Agency Task Force-Operation Sovereign Borders. Retrieved August 29, 2019. https://osb.homeaffairs. gov.au/Files/OSB-organisational-chart.pdf/. 
Dewey, John. 1938. The Later Works of John Dewey. Vol. 12, 1925-1953, Logic: The Theory of Inquiry, ed. JoAnne Boydston. 1991. Carbondale: Southern Illinois University.

1946. The Public and Its Problems: An Essay in Political Inquiry. Chicago: Gateway Books.

Dryzek, John S. 2001. "Legitimacy and Economy in Deliberative Democracy." Political Theory 29(5): 65169.

Erman, Eva. 2016. "Global Political Legitimacy beyond Justice and Democracy?" International Theory 8(1): 2962.

Expert Panel on Asylum Seekers. 2012. "Report of the Expert Panel on Asylum Seekers." Australian Government. Retrieved August 3, 2015 http://apo.org.au/files/Resource/ expert_panel_on_asylum_seekers_full_report_0.pdf.

Farrell, Paul. 2015. "Nauru Asylum Seekers Could Face Jail for Protesting Conditions Under New Law." The Guardian. Retrieved August 3, 2015. http://www. theguardian.com/world/2015/may/13/nauru-asylumseekers-could-face-jail-for-protesting-conditionsunder-new-law.

Floyd, Rita. 2011. "Can Securitization Theory be Used in Normative Analysis? Towards a Just Securitization Theory." Security Dialogue 42(4-5): 427-39.

Floyd, Jonathan. 2016. "Normative Behaviourism and Global Political Principles." Journal of International Political Theory 12(2): 152-68.

Fox, Peter D. 2010. "International Asylum and Boat People: The Tampa Affair and Australia's Pacific Solution". Midwest Journal of International Law 25: 356-73.

Freedman, Lawrence. 1992. "The Concept of Security." In Encyclopedia of Government and Politics, vol. 2, ed. Mary Hawkesworth and Maurice Kogan, 730-741. New York: Routledge.

Fung, Archon. 2013. "Infotopia: Unleashing the Democratic Power of Transparency." Politics \& Society 41(2): 183-212.

Geuss, Raymond. 2009. "What Is Political Judgement?" In Political Judgment: Essays for John Dunn, ed. Richard Bourke and Raymond Geuss. Cambridge: Cambridge University Press.

Givens, Terry, Gary P. Freeman, and David L. Leal. 2008. Immigration Policy and Security: US, European, and Commonwealth Perspectives. New York: Routledge.

Goodhart, Michael. 1995. Democracy as Human Rights: Freedom and Equality in an Age of Globalization. New York: Routledge.

Government of Canada. 2012. Bill C-31: Protecting Canada's Immigration System Act.

Held, David. 2006. Models of Democracy. Cambridge: Polity.

Hirst, Paul. 2013. Associative Democracy: New Forms of Economic and Social Governance. John Wiley \& Sons.
Howard, Jessica. 2003. "To Deter and Deny: Australia and the Interdiction of Asylum Seekers." Refuge 21(4): 35-51.

Hurst, Daniel. 2015. "Tony Abbott Refuses to Rule Out Paying People Smugglers to Turn Back Boats." The Guardian. Retrieved August 3, 2015. http://www. theguardian.com/australia-news/2015/jun/12/tonyabbott-refuses-to-rule-out-paying-people-smugglers-toturn-back-boats.

Ignatieff, Michael. 2004. The Lesser Evil: Political Ethics in an Age of Terror. Toronto: Penguin Canada.

Jabour, Bridie and Daniel Hurst. 2014. "Nauru to Increase Visa Cost for Journalists From $\$ 200$ to $\$ 8,000$." The Guardian. Retrieved August 3, 2015. http:// www.theguardian.com/world/2014/jan/09/nauru-visato-cost-8000.

Knight, Jack and James Johnson. 1994. "Aggregation and Deliberation: On the Possibility of Democratic Legitimacy." Political Theory (22)2: 277-96.

Landemore, Hélène. 2012. Democratic Reason: Politics, Collective Intelligence, and the Rule of the Many. Princeton, NJ: Princeton University Press.

Lazar, Nomi. 2009. States of Emergency in Liberal Democracies. Cambridge: Cambridge University Press.

Lazarus, Liora. 2015. "The Right to Security." In The Philosophical Foundation of Human Rights, ed. Rowan Cruft, S. Matthew Liao, and Massimo Renzo, 423-441. Oxford: Oxford University Press.

Lenard, Patti Tamara. 2012. Trust, Democracy and Multicultural Challenges. University Park: Penn State Press.

Liew, Jamie. 2011. "Managing the Fear of the Tsunami: Canada's Proposed Policy to Detain Boat People and Lessons Learned From the United States' Detention Policies." Rutgers Race and Law Review 13: 1-68.

Library of Parliament (Canada). 2012. "Legislative Summary, Bill C-31, An Act to Amend the Immigration and Refugee Protection Act." http://publications.gc.ca/ collections/collection_2012/bdp-lop/ls/41-1-c31-1eng.pdf.

Loader, Ian and Neil Walker. 2007. Civilizing Security. New York: Cambridge University Press.

Macdonald, Terry. 2016. "Institutional Facts and Principles of Global Political Legitimacy.” Journal of International Political Theory 12(2): 134-51. . 2017. "Democratizing Global 'Bodies Politic': Collective Agency, Political Legitimacy, and the Democratic Boundary Problem." Global Justice: Theory Practice Rhetoric 10(2): 22-42.

2018. "Sovereignty, Democracy, and Global Political Legitimacy." In The Oxford Handbook of International Political Theory, ed. Chris Brown and Robyn Eckersley. Oxford: Oxford University Press.

2019. Global Political Legitimacy: A Normative

Theory of Pluralist World Order. Unpublished book manuscript. 
Macdonald, Kate and Terry Macdonald. 2017. "Liquid Authority and Political Legitimacy in Transnational Governance." International Theory 9(2): 329-51.

Macdonald, Terry and Kate Macdonald. Forthcoming. "Towards a 'Pluralist' World Order: Creative Agency and Legitimacy in Global Institutions." European Journal of International Relations. DOI: 10.1177/1354066119873134.

Mathew, Penelope. 2002. "Australian Refugee Protection in the Wake of the Tampa." American Society of International Law, 96(3): 661-676.

McDonald, Matt. 2008. "Securitization and the Consruction of Security." European Journal of International Relations. 14(4): 563-587.

Meisels, Tamar. 2008. The Trouble with Terror: Liberty, Security and the Response to Terrorism. Cambridge, UK: Cambridge University Press.

Miller, David. 1992. "Deliberative Democracy and Social Choice." Political Studies 40(1_suppl): 54-67.

- 1995. On Nationality. Oxford: Clarendon Press.

Newey, Glen. 2012. "Liberty, Security Notwithstanding." In Social Cohesion, Securitization and Counter-terrorism, ed. Charles Husband and Yunis Alam. Helsinki: Helsinki Collegium for Advanced Studies, 1-21.

Parliament of Canada. 2012a. "House of Commons Standing Committee on Citizenship and Immigration Minutes of Proceedings, 41st Parliament, 1st session: meeting 31." Retrieved August 3, 2015. http://www.parl.gc.ca/ HousePublications/Publication.aspx?DocId $=5525470 \&$ Language $=\mathrm{E} \&$ Mode $=1$.

_ 2012b. "House of Commons, Edited Hansard." Retrieved August 3, 2015 http://www.parl.gc.ca/ HousePublications/Publication.aspx?Pub= Hansard $\&$ Doc $=90 \& \operatorname{Parl}=41 \&$ Ses $=1 \&$ Language $=$ $\mathrm{E} \&$ Mode $=1 \# 6841714$.

- 2012c. "House of Commons, Edited Hansard." Retrieved August 3, 2015 http://www.parl.gc.ca/ HousePublications/Publication.aspx?Pub $=$ Hansard $\&$ $\mathrm{Doc}=90 \& \mathrm{Parl}=41 \& \mathrm{Ses}=1 \&$ Language $=\mathrm{E} \& \mathrm{Mode}=$ $1 \&$ DocId $=5474617 \&$ File $=0$.

Phillips, Janet. 2014. "A Comparison of Coalition and Labor Government Asylum Policies in Australia since 2001." Parliament of Australia, Department of Parliamentary Services, Research Paper Series. Retrieved August 3, 2015 http://parlinfo.aph.gov.au/parlInfo/ download/library/prspub/3024333/upload_binary/ 3024333.pdf;fileType $=$ application $\% 2 \mathrm{Fpdf}$.

Philp, Mark. 2007. Political Conduct. Cambridge, MA: Harvard University Press.

Przeworski, Adam and Susan C. Stokes. 1999. Democracy, Accountability, and Representation. Vol. 2. Cambridge: Cambridge University Press.

Rawls, John. 2005. Political Liberalism. New York: Columbia University Press.

Rossi, Enzo and Matt Sleat. 2014. "Realism in Normative Political Theory." Philosophy Compass 9(10): 689-701.
Rudolph, Christopher. 2006. National Security and Immigration: Policy Development in the United States and Western Europe since 1945. Stanford, CA: Stanford University Press.

Sagar, Rahul. 2007. "On Combatting the Abuse of State Secrecy.” Journal of Political Philosphy 15(4): 404-27. . 2013. Secrets and Lies: The Dilemma of State Secrecy. Princeton, NJ: Princeton University Press.

Salter, Mark, ed. 2008. Politics at the Airport. Minneapolis: University of Minnesota Press.

Saward, Michael. 1998. The Terms of Democracy. Cambridge: Polity Press.

Shue, Henry. 1996. Basic Rights: Subsistence, Affluence and U.S. Foreign Policy. 2nd ed. Princeton, NJ: Princeton University Press.

Silverman, Stephanie. 2014. "In the Wake of Irregular Arrivals: Changes to the Canadian Immigration Detention System." Refuge 30(2): 27-34.

Taylor, Isaac. 2018. The Ethics of Counterterrorism. New York: Routledge.

Tranter, Kellie. 2014. "No Comment on Operations: How Morrison's media strategy took shape." The Guardian. Retrieved August 3, 2015. http://www. theguardian.com/commentisfree/2014/jul/10/nocomment-on-operations-how-morrisons-mediastrategy-took-shape.

United Nations. 2015. "International Migration 2015." Department of Economic and Social Affairs (Population Division). Retrieved August 3, 2015. http:// www.un.org/en/development/desa/population/ migration/publications/wallchart/docs/ MigrationWallChart2015.pdf.

Valentini, Laura. 2012. "Assessing the Global Order: Justice, Legitimacy, or Political Justice?” Critical Review of International Social and Political Philosophy 15(5): 593-612.

Waldron, Jeremy. 2003. "Security and Liberty: The Image of Balance." Journal of Political Philosophy 11(2): 191210.

. 2012. "Safety and Security." In Civil Liberties, National Security and the Prospects for Consensus, ed. Esther D. Reed and Michael Dumper. Cambridge, UK: Cambridge University press, 13-34.

Warren, Mark E. 2001. Democracy and Association. Princeton, NJ: Princeton University Press.

Watson, Scott. 2007. "Manufacturing Threats: Asylum Seekers as Threats or Refugees." Journal of International Law and International Relations 3(1): 95117.

Whitaker, Reginald. 1987. Double Standard: The Secret History of Canadian Immigration Policy. Toronto: Lester \& Orpen Dennys, Ltd.

Williams, Bernard A. O. 2005. In the Beginning was the Deed: Realism and Moralism in Political Argument Princeton, NJ: Princeton University Press. 
Williams, Michael C. 2011. "Securitization and the Liberalism of Fear." Security Dialogue 42: 453-63. 2015. "Securitization as Political Theory: The Politics of the Extraordinary." International Relations 29(1): 114-20.

Wolfendale, Jessica. 2017. "Moral Security." Journal of Political Philosophy (25)2: 238-55.

Wolfers, Arnold. 1952. "National Security" as an Ambiguous Symbol.” Political Science Quarterly (67)4: 481-502.

Wright, Tony. 2014. "Manus Island Events 'Tragic and Distressing' But Who is Accountable?" The Guardian.
Retrieved August 3, 2015. http://www.smh.com.au/ federal-politics/political-opinion/manus-island-eventstragic-and-distressing-but-who-is-accountable20140526-38zlc.html\#ixzz3i5p6QRLU.

Youssef, Marten. 2010. "More Tamil Vessels May be Headed for Canada." Globe and Mail, August 5.

Zedner, Lucia. 2005. "Securing Liberty in the Face of Terror: Reflections from Criminal Justice." Journal of Law and Society 32: 507-33.

Zureik, Elia and Mark Salter (eds.). 2008. Global Surveillance and Policing: Borders, Security, Identity. UK: Willan Publishing. 